\title{
The Role of Monocyte-Derived Cells and Inflammation in Baboon Ductus Arteriosus Remodeling
}

\author{
NAHID WALEH, STEVEN SEIDNER, DONALD MCCURNIN, BRADLEY YODER, BAO MEI LIU, \\ CHRISTINE ROMAN, FRANÇOISE MAURAY, AND RONALD I. CLYMAN \\ Cardiovascular Research Institute [B.M.L., C.R., F.M., R.I.C.], Department of Pediatrics [R.I.C.], \\ University of California, San Francisco, San Francisco, California 94143, Pharmaceutical Discovery \\ Division [N.W.], SRI International, Menlo Park, California 94025, Department of Pediatrics [S.S., D.M.], \\ Department of Pathology [B.Y.], University of Texas, San Antonio, Texas 78284
}

\begin{abstract}
Inflammatory processes play a crucial role in the pathogenesis of atherosclerosis and other vascular disorders. We hypothesized that ischemia of the ductus arteriosus might initiate an active inflammatory response that could play a role in ductus remodeling and permanent closure. To test this hypothesis, we studied effects of postnatal ductus construction on inflammatory processes and remodeling in late-gestation fetal and newborn baboons, and preterm newborn baboons. After postnatal ductus constriction, the expression of several genes known to be essential for atherosclerotic remodeling [vascular cell adhesion molecule (VCAM)-1, E-selectin, IL-8, macrophage colony stimulating factor-1, CD154, interferon- $\gamma$, IL-6, and tumor necrosis factor- $\alpha$ ] was increased in the ductus wall. We were unable to detect intercellular adhesion molecule (ICAM)-1, ICAM-2, Pselectin, monocyte chemoattractant protein-1, or IL-1 by either real-time PCR or immunohistochemistry. VCAM-1, which is newly expressed by luminal cells of the closed ductus, is an important ligand for the mononuclear cell adhesion receptor VLA4. After postnatal constriction, VLA4 ${ }^{+}$monocytes/ macrophages $\left(\mathrm{CD}^{+} 8^{+}\right.$and $\left.\mathrm{CD} 14^{+}\right)$and, to a lesser extent, T-lymphocytes adhered to the ductus wall. Neutrophils and platelets were not observed. The extent of postnatal neointimal
\end{abstract}

\section{ABSTRACT}

remodeling (both endothelial cell layering and subendothelial space thickening) was associated with the degree of mononuclear cell adhesion. Similarly, the extent of vasa vasorum ingrowth correlated with the invasion of $\mathrm{CD}^{+} 8^{+}$cells, from the adventitia into the muscle media. Based on these data, we conclude that the inflammatory response following postnatal ductus constriction may be as necessary for ductus remodeling as it is for atherosclerotic remodeling. (Pediatr Res 57: 254-262, 2005)

$\quad$ Abbreviations
IBU, ibuprofen
ICAM, intercellular adhesion molecule
IFN- $\gamma$, interferon- $\gamma$
INDO, indomethacin
L-NA, $N$-nitro-L-arginine
MCP, monocyte chemoattractant protein
MMA, $N$-monomethyl-L-arginine-monoacetate
MDH, malate dehydrogenase
TNF- $\boldsymbol{\alpha}$, tumor necrosis factor- $\alpha$
VCAM, vascular cell adhesion molecule
VEGF, vascular endothelial growth factor

Closure of the full-term ductus arteriosus occurs in two phases. First, smooth muscle constriction obstructs the ductus' lumen. Then, anatomic remodeling permanently occludes the lumen. The initial constriction appears to be the required stimulus for anatomic closure. During constriction, loss of luminal and vasa vasorum flow produce a zone of ischemic-

Received March 9, 2004; accepted July 19, 2004.

Correspondence: Ronald I. Clyman, M.D., Box 0544, HSE 1492, University of California, San Francisco, 513 Parnassus Ave., San Francisco, CA 94143-0544, e-mail: ric@itsa.ucsf.edu

Supported, in part, by U.S. Public Health Service National Heart, Lung, Blood Institute grants HL 46691, HL 56061, and HL52636.

DOI: 10.1203/01.PDR.0000148278.64777.EF hypoxia in the ductus' muscle media that induces the following anatomic changes: luminal endothelial proliferation, subendothelial thickening, ingrowth of vasa vasorum, and cell death (1). The preterm newborn is capable of remodeling its ductus, just like the full-term newborn, if it can impede its luminal flow and develop the same degree of ischemic-hypoxia as found at term (2).

Although the cell death and ingrowth of vasa vasorum in the ductus wall appear to be due to ATP depletion $(3,4)$ and VEGF induction (5), respectively, the mechanism(s) responsible for the neointimal changes are still unknown. It is now clear that inflammatory processes play a crucial role in the pathogenesis of several vascular disorders (6-9). The most studied model of 
vascular inflammation is atherosclerosis, where the accumulation of monocytes/macrophages in the vessel wall plays an early role in remodeling (10). The monocytes/macrophages elaborate numerous factors that help to orchestrate the subsequent neointimal changes $(8,9)$. Recently, several cytokinesproinflammatory [IL-6 $(11,12), \mathrm{TNF}-\alpha(13,14)$, IL-1 $(13,14)]$, chemotactic [MCP-1 (15), IL-8 (16)], immunomodulatory [MCSF $(10,17)$, IFN- $\gamma(18)$, CD154 $(19,20)]$ - and adhesion molecules-P-selectin (21,22), E-selectin (21), ICAM-1 (22,23), VCAM-1 (23), and VLA4 integrin (24) — have been shown to play an essential role during atherosclerotic remodeling.

We hypothesized that, after postnatal constriction and loss of luminal blood flow, an active inflammatory process might play an important role in ductus arteriosus remodeling and permanent closure. In the studies described below, we found that, after postnatal constriction, monocytes/macrophages adhere to the ductus wall, their accumulation appears to be related to the types of cytokines and adhesion molecules induced after constriction, and the extent of neointimal remodeling is directly related to the degree of mononuclear cell adhesion.

\section{METHODS}

All studies were approved by the committees on animal research at the University of California San Francisco, the University of Texas Health Science Center, and the Southwest Foundation for Biomedical Research.

We used fetal and newborn baboons (Papio sp., full term $=185 \mathrm{~d}$ gestation) to examine the effects of ductus constriction on ductus remodeling. Animal care, surgery, and necropsy were performed as previously described $(1,2)$. Preterm [ $125 \mathrm{~d}$ gestation ( $68 \%$ of full term)] and mature ( $175 \mathrm{~d}$ gestation) fetal baboons were delivered by cesarean section and euthanized before breathing. Preterm newborn baboons were delivered by cesarean section at $125 \mathrm{~d}$ gestation and were euthanized on d 6 after delivery. Mature full-term newborn baboons were euthanized between 1 and $2 \mathrm{~d}$ after spontaneous full-term delivery.

Our primary goal was to examine the difference in inflammatory response between preterm newborn ductus that remain patent after birth and those that close after birth. A complete echocardiographic exam including assessment of ductal patency was performed daily using an $8-\mathrm{mHz}$ transducer interfaced with a Biosound AU3 (Genoa, Italy) echocardiographic system (2). At necropsy, the ductus was dissected in $4^{\circ} \mathrm{C}$ PBS solution and frozen in liquid nitrogen (for RNA analysis) or embedded in Tissuetek (American Master Tech, Merced, CA) and frozen in liquid nitrogen.

Preparation of total RNA, reverse transcription, and quantitative PCR. Total RNA was isolated from the frozen ductus of eight preterm fetuses, six preterm newborns (whose ductus had closed spontaneously by $5 \mathrm{~d}$ after delivery), eight preterm newborns (whose ductus were still patent before necropsy on $\mathrm{d} 6$ ), eight mature fetuses ( $175 \mathrm{~d}$ gestation), and eight full-term 1to 2-d-old newborns, as described elsewhere (25). We used the TaqMan Universal PCR master mix of PE Applied Biosystems (Foster City, CA) to quantify the expression of molecules involved in vascular remodeling and inflammation. TaqMan probes were designed using the Primer Express program and labeled with fluorophores, 6-caboxy-fluorescein and 6 carboxytetramethyl-rhodamine, as reporter and quencher dyes, respectively. An ABI PRISM 7700 Sequence detection system was used to determine number of PCR cycles required for product detection [cycle threshold (CT value)]. Reactions were carried out in triplicate. The fewer the number of starting copies of a gene (mRNA), the higher the CT value required for product detection. All reactions were repeated on at least three separate days. Data were analyzed using the Sequence Detector version 1.6.3 program.

In preliminary experiments, we found that in the fetal and newborn ductus the $\mathrm{CT}$ value of the baboon housekeeping gene MDH was constant throughout gestation and after birth: CT (fetus $125 \mathrm{~d}$ ) $=30.1 \pm 0.4$ cycles, $n=8$; CT (fetus $175 \mathrm{~d}$ ) $=30.0 \pm 0.4, n=8 ; \mathrm{CT}$ (full term newborn) $=30.2 \pm 0.3, n=8$.
Therefore, MDH could be used as an internal control to normalize the degree of expression of any gene under investigation. We used the method of relative gene expression, where $\triangle \mathrm{CT}(\mathrm{MDH}-$ gene) represents the difference in cycle threshold between MDH and the individual gene of interest. Each unit of $\triangle \mathrm{CT}$ (MDH gene) represents a 2-fold increase in a gene's mRNA. The more negative the $\Delta \mathrm{CT}$ (MDH - gene), the fewer the number of starting copies of a gene.

We have previously shown that the expression of VEGF mRNA in the ductus arteriosus correlates with the degree of smooth muscle hypoxia (5). In our real-time PCR experiments, we used VEGF as a surrogate marker for hypoxia.

Immunohistochemistry: in vivo preparation. Our primary goal was to examine the differences between preterm newborn ductus that remain patent after birth and those that close after birth. Preterm newborn baboons frequently fail to constrict their ductus and obstruct their luminal blood flow after birth unless they are treated with inhibitors of both prostaglandin and nitric oxide production (2). Therefore, we treated preterm newborn baboons with one of five protocols to obtain a sufficient number of closed ductus for immunohistochemical analysis: group $1-$ INDO alone (INDO, $n=6$ ); group 2-INDO plus L-NA (a nitric oxide synthase inhibitor) (INDO $+\mathrm{L}-\mathrm{NA}, n=6$ ); group 3-INDO plus MMA (a nitric oxide synthase inhibitor) (INDO+MMA, $n=$ 6); group 4-ibuprofen alone (IBU, $n=6$ ); group 5-no treatment (control, $n=10$ ). These treatment protocols have been previously described (2). INDO (Indocin, $0.1 \mathrm{mg} / \mathrm{kg} / \mathrm{dose}$ ) was given intravenously at 24, 48, 72, 84, 96, 108, 120 , and $132 \mathrm{~h}$ after delivery to animals in groups 1,2 , and 3. Groups 2 and 3 received continuous infusions of either L-NA $(6 \mathrm{mg} / \mathrm{kg} / \mathrm{h})$ or MMA (20 $\mathrm{mg} / \mathrm{kg} / \mathrm{h}$ ), respectively, starting at $50 \mathrm{~h}$ after delivery, which continued until necropsy. Group 4 received i.v. ibuprofen (Farmacon, Westport, CT) $10 \mathrm{mg} / \mathrm{kg}$ at $24 \mathrm{~h}$ and $5 \mathrm{mg} / \mathrm{kg}$ at $48,72,96$, and $120 \mathrm{~h}$ after delivery.

On the day of necropsy, the ductus was closed on Doppler exam in $3 / 6$ INDO-treated, 6/6 INDO+L-NA-treated, 6/6 INDO+MMA-treated, 6/6 IBUtreated, and 3/10 control preterm newborn baboons. We have previously shown that the histologic changes that occur during ductus remodeling depend on the degree of ductus constriction and vessel wall ischemia, and not on the pharmacologic manipulations used to produce the constriction $(1,2)$. Therefore, we sorted the ductus from the five different preterm newborn treatment groups into two groups: immature newborn ductus closed at necropsy $(n=24)$ and immature newborn ductus open at necropsy $(n=10)$.

Immunohistochemistry. Immunohistochemistry protocols were similar to those reported previously (2,26). Endothelial cells were detected with antiendothelial nitric oxide synthase (Clone 3, BD Biosciences, San Jose, CA) and anti-CD31 (9G11, R \& D Systems, Minneapolis, MN). Both antibodies showed identical findings. Antibodies against the following leukocyte antigens were used to identify mononuclear cells in the ductus wall: VLA4 [lymphocytes, dendritic cells and activated monocyte/macrophages: BU49 (Calbiochem, San Diego, CA)], CD68 [lymphocytes, dendritic cells, activated monocytes/macrophages, and granulocytes: KP1 (DAKO, Carpinteria, CA)], CD3 [T-lymphocytes: rabbit polyclonal (DAKO)], CD14 [monocytes/macrophages: TUKU (DAKO)], CD83 [mature dendritic cells: HB15a (Santa Cruz Biotechnology, Santa Cruz, CA)], neutrophil elastase [granulocytes: NP57 (DAKO)], and $G P 1 b \alpha$ [platelets: AN51 (DAKO)]. Antibodies against VCAM-1 [1G11 (Santa Cruz Biotechnology)], ICAM-1 [15.2 (Santa Cruz Biotechnology and Calbiochem)], ICAM-2 [F5 (Santa Cruz Biotechnology)], E-selectin [1.2B6 (Santa Cruz Biotechnology)], and P-selectin [1E3 (Santa Cruz Biotechnology) and AK4 (BD Biosciences)] were used to identify adhesion molecules expressed by activated endothelial cells. The number of positively stained cells lining the ductus lumen was expressed per 100 luminal-lining cells.

Histologic measurements in the newborn ductus were made at the level of minimal luminal area, which was determined from $6-\mu \mathrm{m}$ serial cross-sections. The subendothelial zone was defined as the region between the luminal endothelial cells and the internal elastic lamina (identified by phase-contrast microscopy).

Mononuclear cells and vasa vasorum invade the ductus muscle media from the surrounding adventitia (see below). To determine the extent of muscle media invasion by mononuclear cells and vasa vasorum, we used an overlay template, containing a grid, and NIH Image software to divide the muscle media into 12 clock hours. In each clock hour section of the wall, we measured the maximal distance that the cells migrated from the adventitia into the media (expressed as a percentage of the distance from the adventitia to the lumen in that clock hour section of the wall). The maximal distances from each of the 
12 sections of the ductus wall were averaged and reported as "percentage medial thickness" for that vessel.

Statistics. Results are presented as means \pm standard deviations, percentages, and correlation coefficients. Intergroup differences were evaluated with either a $\chi^{2}$ analysis, or unpaired $t$ test. When more than one comparison was made, Bonferroni's correction was used.

\section{RESULTS}

The full-term newborn baboon ductus constricts rapidly after birth and is closed by Doppler exam within $12 \mathrm{~h}$ after delivery. In contrast with the mature fetal ductus, which has a single endothelial cell layer lying close to the internal elastic lamina for the majority of the luminal circumference, the full-term



B) Thickened Subendothelial Zone $(>20 \mu \mathrm{m})$

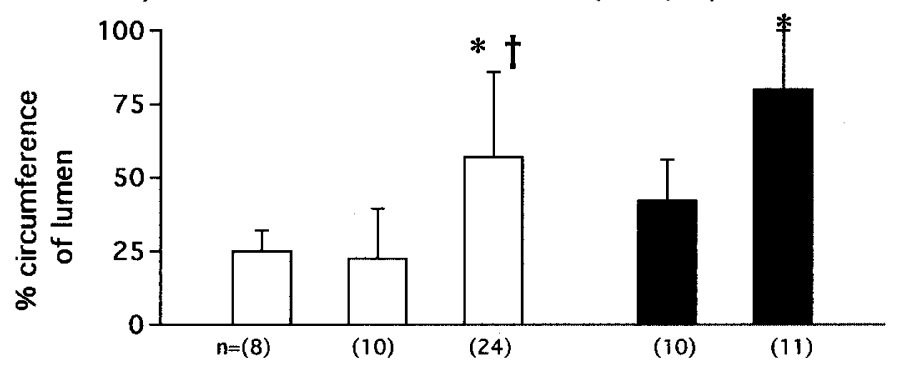

C) Vasa Vasorum Ingrowth



Figure 1. Relationship between the degree of ductus constriction and ductus remodeling. (A) Fetal and neonatal ductus from immature and mature baboons were categorized as having either areas along the lumen with multiple (three or more) layers of $\mathrm{CD} 31^{+}$luminal endothelial cells (multiple layers) or a single layer of $\mathrm{CD}_{3} 1^{+}$cells that completely surrounds the lumen (single layer). The vertical bars represent the number of ductus in a group (expressed as a percentage) that have areas with multiple layers of endothelium. Nb-open, newborn with a patent ductus at necropsy; $\mathrm{Nb}$-closed, newborn with a closed ductus at necropsy. (B) Subendothelial zone thickness is distance between endothelial layer and internal elastic lamina. The percentage of the luminal circumference that is surrounded by a thickened $(>20 \mu \mathrm{m})$ subendothelial zone is increased after postnatal constriction. $(C)$ The distance that vasa vasorum migrate from the adventitia into the muscle media is expressed as the percentage medial thickness (see "Methods"). ${ }^{*} p<0.05 v s$ fetal ductus; $\uparrow p<$ 0.05 vs newborn-open. $N$, number of ductus examined. newborn ductus undergoes extensive neointimal expansion during the first $2 \mathrm{~d}$ after birth. This includes the appearance of multiple endothelial cell layers and thickening of the subendothelial zone (by migrating smooth muscle cells, matrix and edema) (Fig. 1, $A$ and $B$ ) (1). In addition, vasa vasorum increase their penetration into the outer muscle media of the mature newborn ductus (Fig. 1C).

The histology of the immature fetal ductus is similar to that of the mature fetal ductus except for fewer areas of subendothelial thickening and less vasa vasorum ingrowth. Little change occurs in the immature newborn ductus that remain patent after birth (Fig. 1). In contrast, the immature newborn ductus that close after birth undergo the same changes that occur in the mature newborn ductus (Fig. 1).

We used VEGF gene expression (mRNA) as a surrogate marker for hypoxia. VEGF expression is increased in the baboon ductus after birth, but only following ductus closure; there is no change in VEGF expression after birth if the ductus
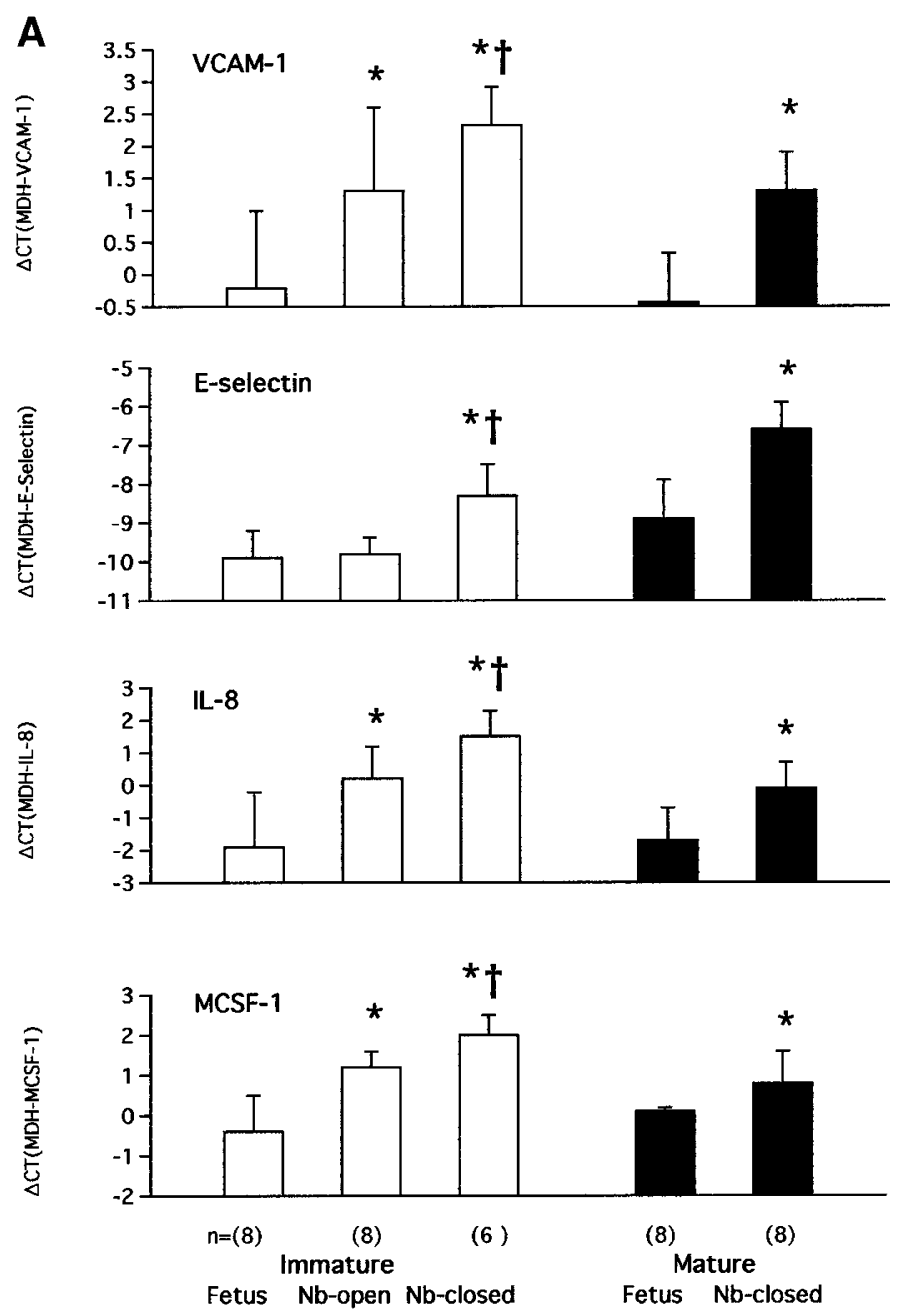

Figure 2. Real-time PCR measurements of genes known to affect vascular remodeling. Ten nanograms of cDNA from individual ductus were placed in separate wells and analyzed by TaqMan real-time PCR. $\triangle \mathrm{CT}(\mathrm{MDH}-$ gene) represents the difference in cycle threshold (CT) between the expression of housekeeping gene $\mathrm{MDH}$ and the individual gene of interest. Each unit of $\triangle \mathrm{CT}(\mathrm{MDH}-$ gene) represents a 2-fold increase in a gene's mRNA. The more negative the $\triangle \mathrm{CT}(\mathrm{MDH}-$ gene), the fewer the number of starting copies of a gene (mRNA). (A) Genes affecting mononuclear cell recruitment. 
remains patent $[\Delta \mathrm{CT}(\mathrm{MDH}-\mathrm{VEGF})$ : immature (fetus $=0.47$ \pm 0.31 , newborn-open ductus $=0.43 \pm 0.30$, newbornclosed ductus $=2.82 \pm 0.60 ; p<0.05$ versus immature fetal ductus); mature (fetus $=-0.49 \pm 0.36$, newborn-closed ductus $=2.03 \pm 0.18 ; p<0.05$ versus mature fetal ductus $)]$.

Many of the genes found to be essential for atherosclerotic remodeling (VCAM-1, E-selectin, IL-8, macrophage colony stimulating factor-1, CD154, IFN- $\gamma$, IL-6, and TNF- $\alpha$ ) are also expressed after postnatal ductus constriction (Fig. 2, $A$ and $B$ ). Several of these genes are increased, even in the face of persistent postnatal patency, and, therefore, must be regulated by hypoxia and by other mechanisms.

On the other hand, several genes found to be necessary for atherogenesis are either not found or are not altered during ductus remodeling. We were unable to detect ICAM-1, ICAM-2, P-selectin, MCP-1, or IL-1 by either real-time PCR [ICAM-1, P-selectin, MCP-1, IL-1 (Fig. 2C)] or immunohistochemistry [ICAM-1, ICAM-2, P-selectin (data not shown)].

During atherosclerotic remodeling, circulating leukocytes use inducible ligands to roll ( $\mathrm{P}$ - and E-selectin) and firmly adhere (ICAM-1 and VCAM-1) to the vessel's endothelium. Among these ligands, only E-selectin and VCAM-1 were found to be regulated during ductus closure and remodeling (Figs. 2A, 3, and 4). Cells lining the ductus lumen increased

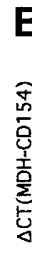

B


Fig. 2b. (B) Immunomodulatory genes. their expression of E-selectin and VCAM-1 after postnatal closure (Figs. 3 and 4).

VCAM-1 is an important endothelial ligand for the VLA4 integrin expressed on circulating mononuclear cells $(9,27)$. The number of $\mathrm{VLA}^{+}$mononuclear cells adhering to the ductus lumen increased after birth (Figs. 3 and 5). The increase in $\mathrm{VLA}^{+}{ }^{+}$cells paralleled the increase in VCAM-1 expression and occurred only after ductus closure and loss of luminal flow (Figs. 4 and 5). The mononuclear cells that adhered to the ductus lumen were positive for monocyte and activated macrophage antigens (CD14 and CD68, respectively; Fig. 3 and 5). There was also a small but significant increase in the number of $\mathrm{CD}^{+} \mathrm{T}$ cells that adhered to the immature ductus lumen after birth; this only occurred after ductus closure (Fig. 5). At the same time, we found a significant increase in CD14 and CD3 mRNA in the ductus after closure: $\triangle \mathrm{CT}(\mathrm{MDH}-\mathrm{CD} 14)$ : immature fetus $=-2.0 \pm 0.3$ versus immature newbornclosed $=0.0 \pm 0.4 ; \Delta \mathrm{CT}(\mathrm{MDH}-\mathrm{CD} 3)$ : immature fetus $=$ $-7.0 \pm 0.8$ versus immature newborn-closed $=-5.5 \pm 0.4$. No platelets $\left(\mathrm{GP} 1 \mathrm{~b} \alpha^{+}\right)$or neutrophils (neutrophil elastasepositive cells) adhered to the fetal or newborn ductus lumen (data not shown). Dendritic cells $\left(\mathrm{CD}^{\circ} 3^{+}\right)$were only occasionally found in the ductus wall (data not shown).

In both the mature and immature ductus, the adhesion of $\mathrm{CD}_{68}{ }^{+}, \mathrm{VLA}_{4}{ }^{+}$, and $\mathrm{CD} 14^{+}$cells to the lumen was signifi-
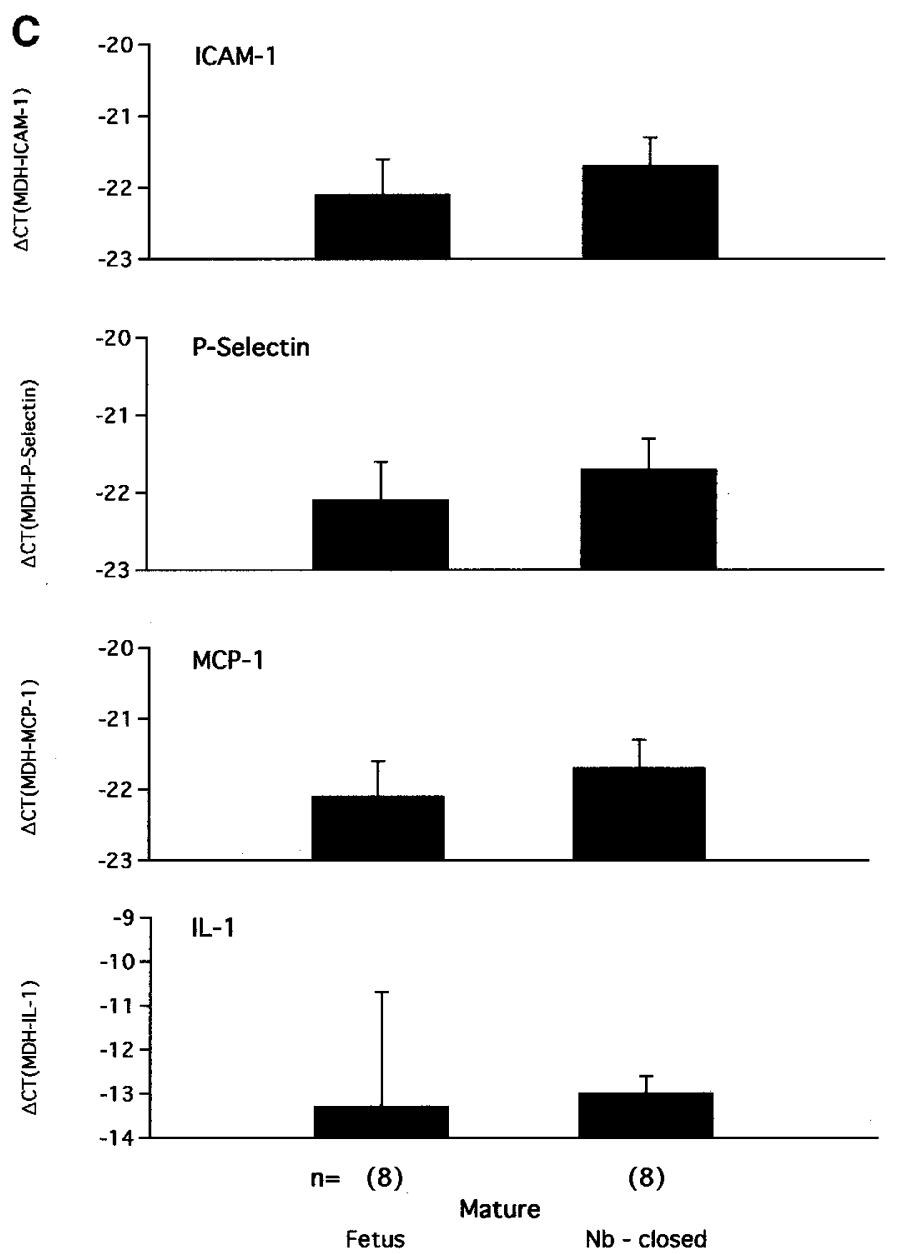

Fig. 2c. $(C)$ Genes not expressed during ductus closure. $* p<0.05$ vs fetal ductus; $\uparrow p<0.05$ vsnewborn-open. $N$, number of ductus examined. 
cantly associated with the presence of multiple endothelial cell layers or mounds (Fig. 6). Similarly, the presence of CD68 ${ }^{+}$ cells in the subendothelial space was significantly associated with a thickened subendothelial zone (Fig. 7).

Resident $\mathrm{CD} 8^{+}$mononuclear cells were present in the adventitia and outer media of the fetal and newborn ductus. $\mathrm{CD}^{+} 8^{+}$cells increased in number and invaded deeper into the muscle media after birth (Fig. 8A). The increased postnatal invasion of $\mathrm{CD}^{+} 8^{+}$cells only occurred after ductus closure and loss of luminal flow (Fig. 8A). The extent of vasa vasorum penetration into the muscle media correlated with the extent of $\mathrm{CD}^{+} 8^{+}$cell invasion [Fig. 8, $B$ (immature) and $C$ (mature)].

\section{DISCUSSION}

During atherosclerotic remodeling, monocytes/macrophages (10) appear to be required for the remodeling process, whereas lymphocytes appear to modulate its progression (28). We found that after postnatal ductus constriction, monocytes/ macrophages and, to a lesser extent, T-lymphocytes, adhere to the ductus lumen and the extent of their recruitment correlates with the degree of neointimal and vasa vasorum remodeling. We hypothesize that mononuclear cell recruitment is as nec- essary for ductus remodeling as it is for atherosclerotic remodeling.

Leukocyte recruitment occurs through a process that involves both leukocyte rolling and adhesion. Rolling is mediated by the interaction of selectins ( $\mathrm{P}-, \mathrm{E}-$, and $\mathrm{L}-)$ with their glycoconjugate ligands, whereas firm adhesion is mediated by the interactions of integrins ( $\beta 2$ subfamily and VLA4) with their respective endothelial ligands (ICAM-1 and VCAM-1) (9). During atherosclerosis, mononuclear cell recruitment and vascular remodeling are dependent on the induced expression of P-selectin, E-selectin, ICAM-1, and VCAM-1 (21-23,29, 30). In contrast, during ductus closure, there is a more limited pattern of adhesion molecule expression: neither P-selectin nor ICAM-1are expressed; only E-selectin and VCAM-1 are increased (Figs. 2, 3, and 4).

In the face of physiologic shear forces, both P- and Eselectin appear to be necessary for leukocyte recruitment $(21,31)$. However, under low-flow conditions, the interaction of VCAM-1 with the VLA4 integrin can mediate rolling and adhesion of monocytes without the need for selectins or $\beta 2$ integrins (32-34). The VLA4/VCAM-1 interaction is less effective in supporting rolling and adhesion of lymphocytes
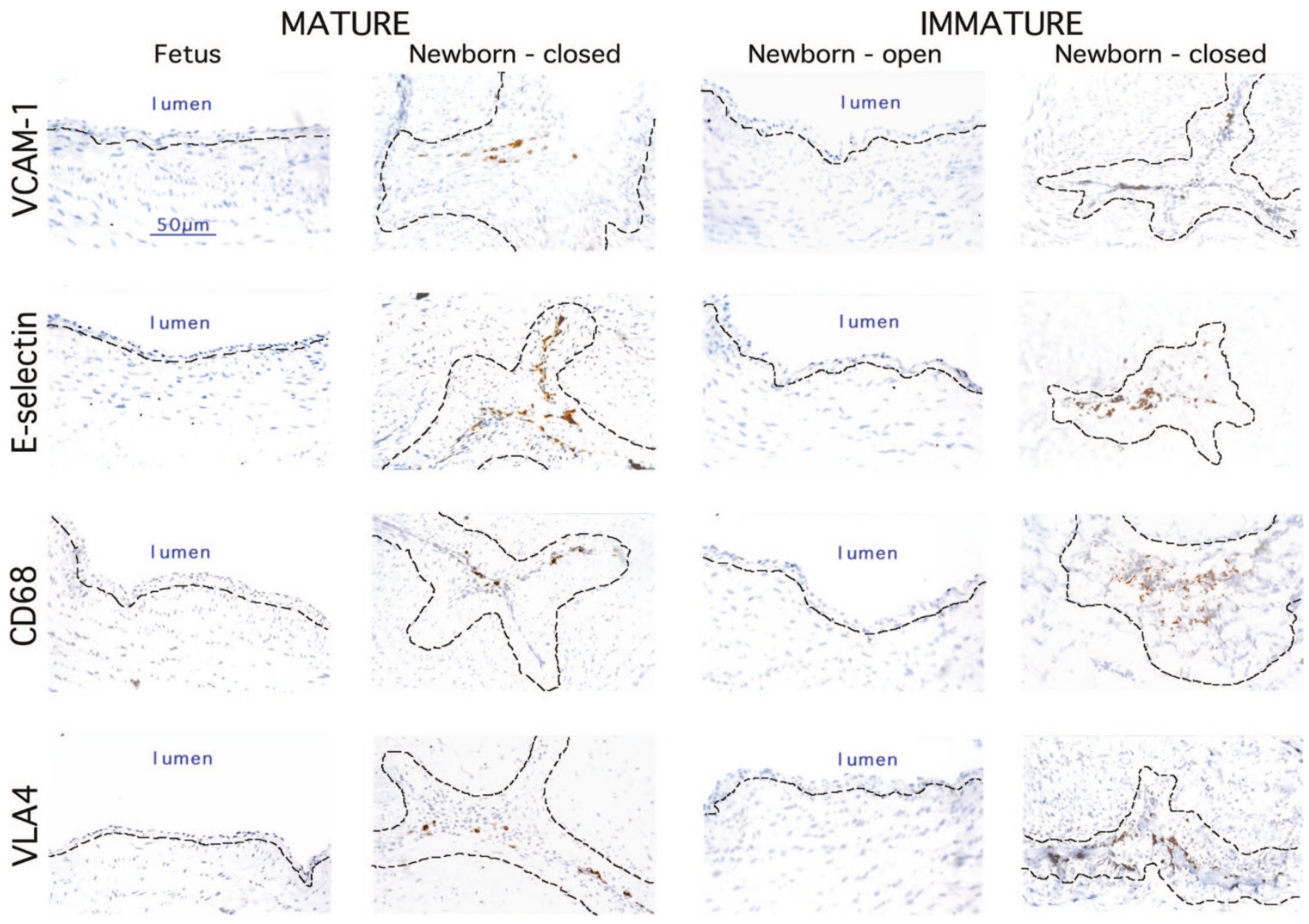

Figure 3. VCAM-1 and E-selectin expression and recruitment of $\mathrm{CD} 68^{+}$and VLA4 $4^{+}$cells are increased during ductus closure. Ductus from mature fetuses (175 d gestation), mature newborns (1- to 2-d-old full-term), immature newborns ( $6 \mathrm{~d}$ old, with or without a patent ductus). Positive immunoreactivity $=$ brown stain. Cell nuclei counterstained with hematoxylin (blue). Dashed black line = internal elastic lamina (identified by phase-contrast microscopy). Horizontal bar represents $50 \mu \mathrm{m}$. Lumen indicates the open lumen of the ductus. See Figures 4 and 5 for quantitation. 
A) VCAM -1

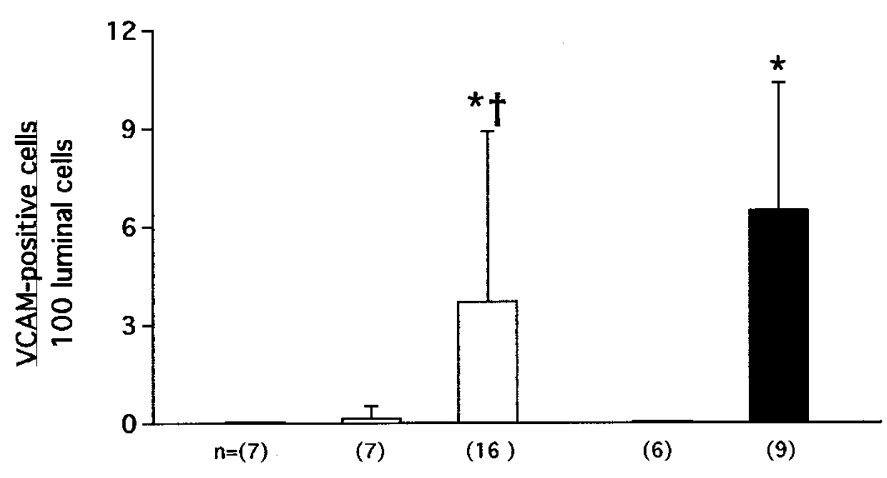

B) E-selectin

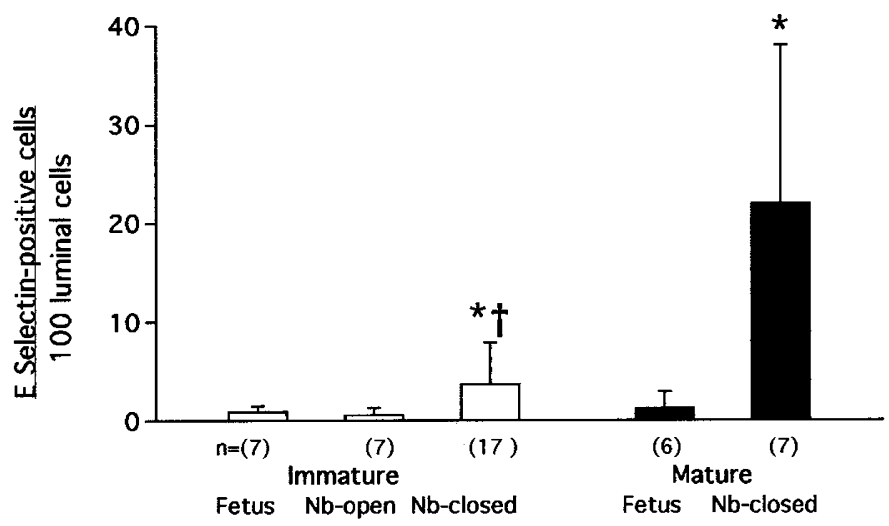

Figure 4. Relationship between the degree of ductus constriction and VCAM-1 and E-selectin expression. The number of cells lining the ductus lumen that are positive (by immunohistochemistry) for VCAM-1 $(A)$ and E-selectin $(B)$ are expressed per 100 lumen-lining cells. ${ }^{*} p<0.05$ vs fetal ductus; $\uparrow p<0.05$ vs newborn-open. $N$, number of ductus examined.

$(35,36)$ and is completely incapable of supporting neutrophil adhesion because VLA4 is not present on neutrophils (27). These findings help to explain why monocytes/macrophages and, to a lesser extent, T cells adhere to the ductus endothelium after ductus closure (Figs. 3 and 5), and why neutrophils, which normally contribute to most inflammatory conditions, are notably absent. We examined the ductus at two time points after birth (immature newborn $=6 \mathrm{~d}$, mature newborn $=1-2$ d); it is possible that other inflammatory cells, in addition to monocyte/macrophages, may play a role during later phases of ductus remodeling.

If mononuclear cell recruitment is necessary for ductus remodeling, then the current studies also help to explain why tight ductus constriction and loss of luminal flow are essential for ductus remodeling and permanent closure $(1,2)$. Decreased luminal flow has a direct effect on VCAM-1 expression (37), promotes cytokine-induced VCAM-1 expression (see below), and enables the interaction of VCAM-1 with VLA4 to support the adhesion of mononuclear cells to the ductus wall in the absence of P-selectin and $\beta 2$ integrin/ICAM-1 interactions.

After postnatal ductus closure, profound hypoxia develops in the ductus wall; this does not occur if the neonatal ductus remains patent after birth $(1,2)$. Our measurements of VEGF
A) VLA4
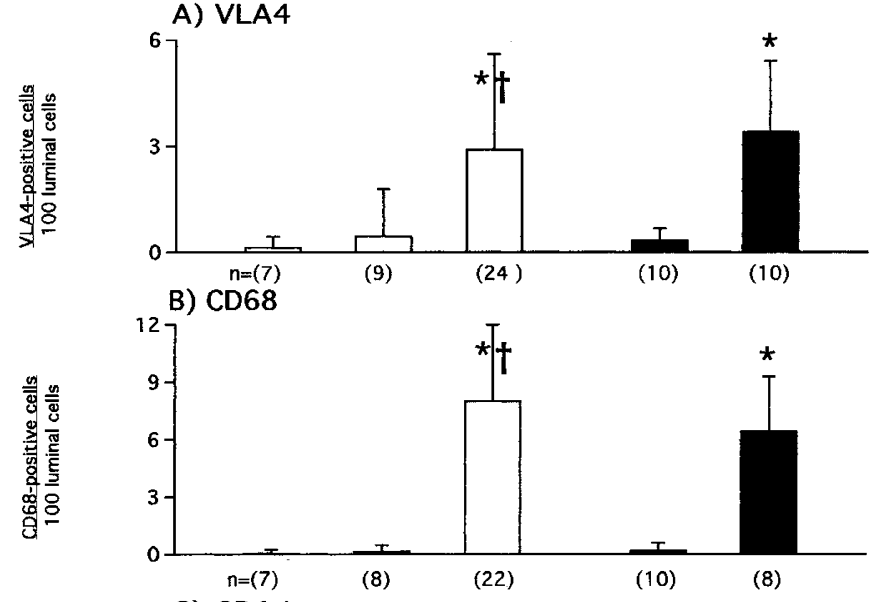

C) $\mathrm{CD} 14$


Figure 5. Relationship between the degree of ductus constriction and mononuclear cell adhesion to the ductus lumen. The number of mononuclear cells [expressing VLA4 $(A)$, CD68 $(B)$, CD14 $(C)$, or CD3 $(D)$ by immunohistochemistry] that adhere to the ductus lumen are expressed per 100 lumen-lining cells. $* p<0.05 v s$ fetal ductus; $\dagger p<0.05 v s$ newborn-open. $N$, number of ductus examined.

gene expression (mRNA) in the fetal and neonatal baboon ductus are consistent with these observations. Several of the cytokines induced during ductus closure [TNF- $\alpha$, IFN- $\gamma$, CD154 (Fig. 2)], are capable of promoting VCAM-1 and E-selectin expression. We hypothesize that ductus wall hypoxic ischemia induces the production of these and the other cytokines (IL-8, macrophage colony stimulating factor-1, and IL-6) known to affect vessel remodeling (10-14,16-20). The pattern of gene expression during ductus closure differs in some respects from that seen during atherosclerosis. Several cytokines (IL-1 and MCP-1) that determine the extent of atherosclerotic remodeling are not expressed during ductus closure (Fig. 2C).

To study the changes in RNA expression that occur during ductus closure, we used preterm newborns whose ductus had closed spontaneously. Because spontaneous ductus closure is a relatively infrequent event (25-30\%) in the preterm newborn baboon (1), we used several pharmacological methods (prostaglandin inhibition with or without nitric oxide inhibition) to ensure an adequate number of closed ductus samples for our immunohistochemical studies. Al- 




B) $\mathrm{CD} 68$

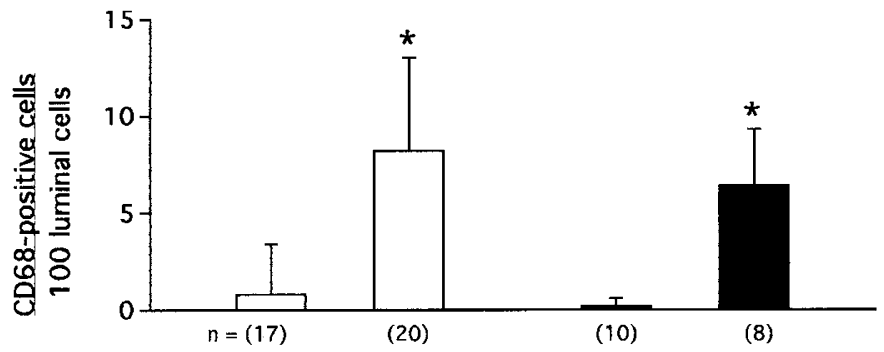

C) $\mathrm{CD} 14$

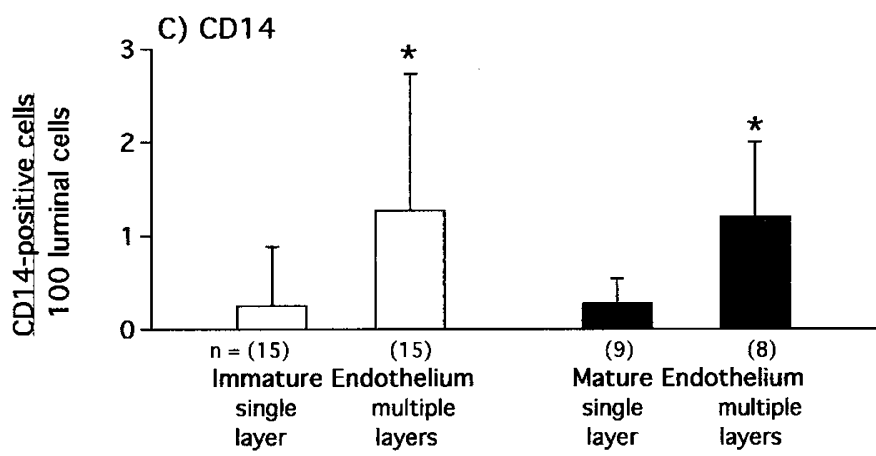

Figure 6. Luminal endothelial accumulation is associated with mononuclear cell adhesion to the ductus lumen. Fetal and neonatal ductus from immature and mature baboons were categorized as having either single or multiple (three or more) layers of $\mathrm{CD} 31^{+}$luminal endothelial cells. The vertical axis represents the number of mononuclear cells [expressing VLA4 $(A)$, CD68 $(B)$, or $\mathrm{CD} 14(C)]$ that adhere to the ductus lumen in each group and is expressed per 100 cells lining the ductus lumen. $* p<0.05$ vs ductus with single layer of endothelial cells. $N$, number of ductus examined.

though inhibition of prostaglandin and nitric oxide production could have altered the inflammatory response in the ductus $(38,39)$, we believe the observed changes are related to ductus closure rather than prostaglandin or nitric oxide inhibition. The same inflammatory and remodeling changes are seen whether or not the ductus close spontaneously, close following prostaglandin inhibition by itself, or close after combined prostaglandin and nitric oxide inhibition. They occur only in the areas of the ductus that are tightly constricted. They are not apparent in the open ends of the ductus near the aortic and pulmonary junctions, nor are they observed in ductus that remain patent despite receiving the same pharmacological treatment protocol.

We hypothesize that the inflammatory response that follows postnatal constriction and loss of luminal flow may be responsible for ductus remodeling and permanent closure. Future studies that interrupt the inflammatory pathway will test this hypothesis more directly.

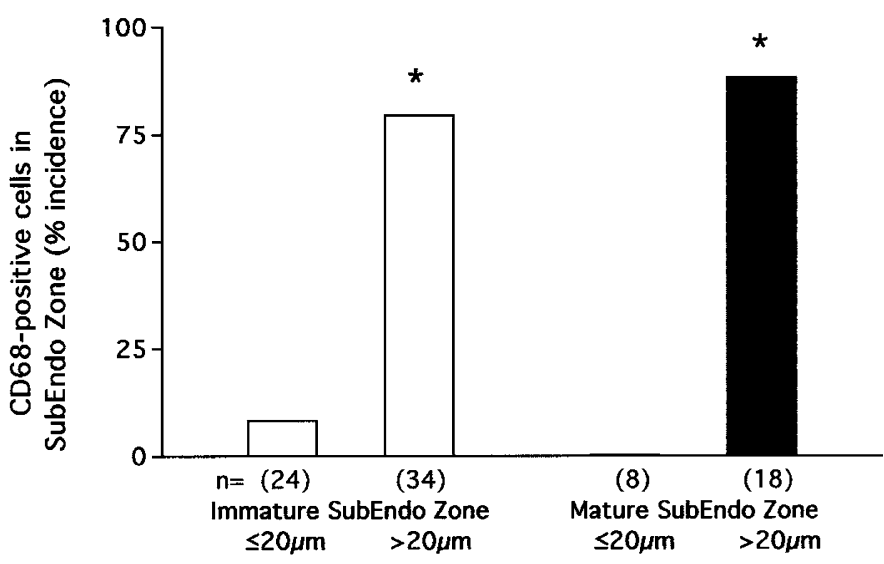

Figure 7. Fetal and newborn ductus from immature $(n=37)$ and mature $(n$ $=18$ ) baboons were examined for the presence of $\mathrm{CD} 68^{+}$cells in the subendothelial zone. In 24/37 immature ductus and 8/18 mature ductus, a subendothelial zone of normal thickness $(\leq 20 \mu \mathrm{m})$ occupied $\geq 50 \%$ of the lumen's circumference (immature $=73+16 \%$ of luminal circumference, mature $=66 \pm 8 \%$ of luminal circumference). In 34/37 immature ductus and $18 / 18$ mature ductus, the subendothelial zone had regions where the thickness exceeded $20 \mu \mathrm{m}$ (thickened subendothelial zones). When they were present, the thickened subendothelial zones encircled $48 \pm 27 \%$ (immature) and $60 \pm$ $28 \%$ (mature) of the luminal circumference. The vertical axis represents the number of subendothelial zones (expressed as percentage incidence) that contain $\mathrm{CD} 68^{+}$cells. $\mathrm{CD}^{+} 8^{+}$cells were present in 79\% (immature) and $88 \%$ (mature) of the thickened subendothelial zones [number of $\mathrm{CD}^{+} 8^{+}$cells/ thickened zone $=3.0 \pm 2.5$ (immature), $5.8 \pm 4.9$ (mature)]; the number of $\mathrm{CD} 8^{+}$cells in the thickened zone correlated with the extent that the thickened subendothelial zone encircled the lumen (number of $\mathrm{CD}^{+} 8^{+}$cells $v s$ percentage of luminal circumference surrounded by thickened subendothelium: immature: $r=0.68, p<0.05$; mature: $r=0.84, p<0.05$ ). In contrast, when normal thickness $(\leq 20 \mu \mathrm{m})$ subendothelial zones (that encircled more than $50 \%$ of the luminal circumference) were examined for the presence of $\mathrm{CD}^{+} 8^{+}$ cells, $\mathrm{CD}_{68}^{+}$cells were present in only $8 \%$ (immature) and $0 \%$ (mature) of the normal thickness zones. ${ }^{*} p<0.05 v s$ number of normal thickness subendothelial zones with $\mathrm{CD}^{+} 8^{+}$cells. $N$, number of subendothelial zones examined.

On the other hand, it is possible that the inflammatory response may have the opposite effects on permanent ductus closure if the ductus fails to constrict after birth. Although the expression of inflammatory cytokines appeared to be related primarily to the degree of ductus constriction, the postnatal expression of several of the cytokines was increased even in the presence of persistent ductus patency (Fig. 2). Several of these cytokines have potent vasodilatory activities (e.g. TNF- $\alpha$, IL-6). After postnatal ductus constriction, ischemia of the ductus wall usually produces cell death and loss of ductus vasoreactivity $(1,40)$. However, when the ductus fails to constrict, and remains patent after birth, it retains its responsiveness to vasoactive stimuli (41). In the presence of persistent ductus vasoreactivity, the postnatal induction of vasodilatory cytokines may play a role in preventing ductus closure after birth. Because these cytokines work through nonprostaglandinmediated pathways (e.g. TNF- $\alpha$, IL-6) (42-45), their presence may explain why indomethacin (which produces ductus constriction primarily by inhibiting prostaglandin production) becomes less effective in constricting the ductus with increasing postnatal age (46). 


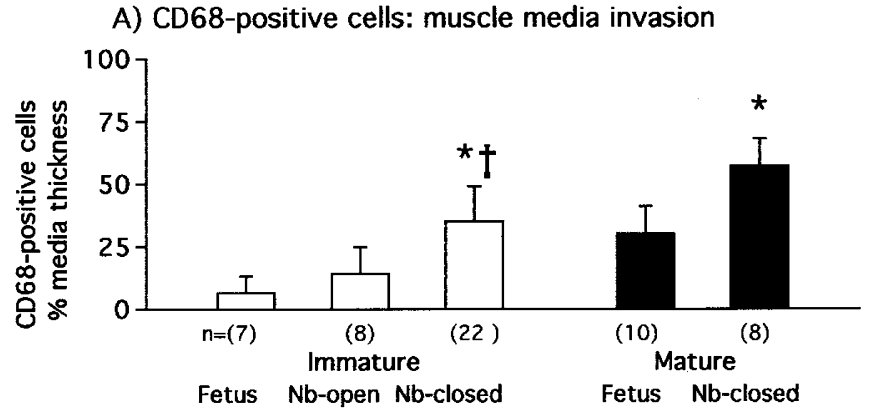

B) Immature: vasa vasorum invasion
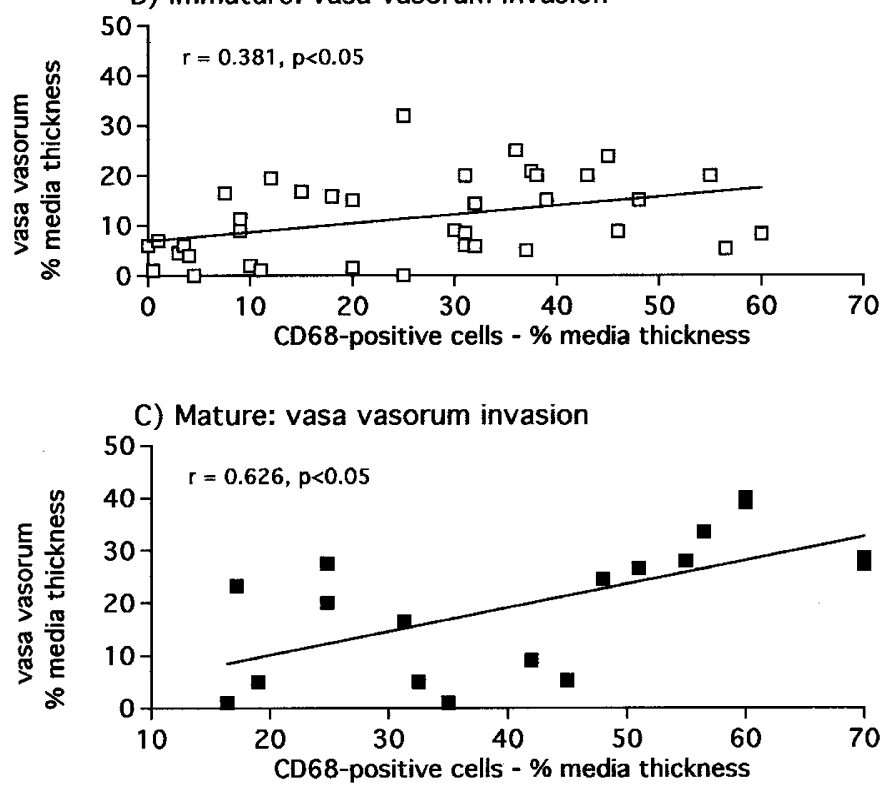

Figure 8. (A) Relationship between the degree of ductus constriction and invasion of the muscle media by $\mathrm{CD}^{+} 8^{+}$mononuclear cells [expressed as percentage of muscle media thickness containing $\mathrm{CD}^{+} 8^{+}$cells (see "Methods")]. * $p<0.05 v s$ fetal ductus; $\uparrow p<0.05 v s$ newborn-open. $N$, number of ductus examined. $(B$ and $C$ ) Fetal and neonatal ductus were stained for CD68 and CD31. There was a significant relationship between the percent of muscle media containing $\mathrm{CD} 68^{+}$cells and the percentage of muscle media containing $\mathrm{CD} 31^{+}$vasa vasorum. (B) Immature: $r=0.38, n=37, p<0.05$. (C) Mature: $r=0.63, n=18, p<0.05$.

\section{REFERENCES}

1. Clyman RI, Chan CY, Mauray F, Chen YQ, Cox W, Seidner SR, Lord EM, Weiss H Wale N, Evan SM, Koch CJ 1999 Permanent anatomic closure of the ductus arteriosus in newborn baboons: the roles of postnatal constriction, hypoxia, and gestation. Pediatr Res 45:19-29

2. Seidner SR, Chen YQ, Oprysko PR, Mauray F, Tse MM, Lin E, Koch C, Clyman RI 2001 Combined prostaglandin and nitric oxide inhibition produces anatomic remodeling and closure of the ductus arteriosus in the premature newborn baboon. Pediatr Res 50:365-373

3. Levin M, Clyman R 2004 ATP depletion, not hypoxia, is responsible for cell death and ductus arteriosus remodeling after birth. Pediatr Res 55:45A

4. Goldbarg S, Quinn T, Waleh N, Roman C, Liu BM, Mauray F, Clyman RI 2003 Effects of hypoxia, hypoglycemia, and muscle shortening on cell death in the sheep ductus arteriosus. Pediatr Res 54:204-211

5. Clyman RI, Seidner SR, Kajino H, Roman C, Koch CJ, Ferrara N, Waleh N, Mauray F, Chen YQ, Perkett EA, Quinn T 2002 VEGF regulates remodeling during permanent anatomic closure of the ductus arteriosus. Am J Physiol Regul Integr Comp Physiol 282:R199-R206

6. Kevil CG, Bullard DC 1999 Roles of leukocyte/endothelial cell adhesion molecules in the pathogenesis of vasculitis. Am J Med 106:677-687

7. Libby P, Ridker PM, Maseri A 2002 Inflammation and atherosclerosis. Circulation 105:1135-1143

8. Glass CK, Witztum JL 2001 Atherosclerosis. The road ahead. Cell 104:503-516

9. Huo Y, Ley K 2001 Adhesion molecules and atherogenesis. Acta Physiol Scand $173: 35-43$
10. Smith JD, Trogan E, Ginsberg M, Grigaux C, Tian J, Miyata M 1995 Decreased atherosclerosis in mice deficient in both macrophage colony-stimulating factor (op) and apolipoprotein E. Proc Natl Acad Sci U S A 92:8264-8268

11. Frostegard J, Ulfgren AK, Nyberg P, Hedin U, Swedenborg J, Andersson U, Hansson GK 1999 Cytokine expression in advanced human atherosclerotic plaques: dominance of pro-inflammatory (Th1) and macrophage-stimulating cytokines. Atherosclerosis 145:33-43

12. Ikeda U, Ikeda M, Seino Y, Takahashi M, Kano S, Shimada K 1992 Interleukin 6 gene transcripts are expressed in atherosclerotic lesions of genetically hyperlipidemic rabbits. Atherosclerosis 92:213-218

13. Barath P, Fishbein MC, Cao J, Berenson J, Helfant RH, Forrester JS 1990 Detection and localization of tumor necrosis factor in human atheroma. Am J Cardiol 65:297302

14. Kishikawa H, Shimokama T, Watanabe T 1993 Localization of T lymphocytes and macrophages expressing IL-1, IL-2 receptor, IL-6 and TNF in human aortic intima. Role of cell-mediated immunity in human atherogenesis. Virchows Arch A Pathol Anat Histopathol 423:433-442

15. Gu L, Okada Y, Clinton SK, Gerard C, Sukhova GK, Libby P, Rollins BJ 1998 Absence of monocyte chemoattractant protein-1 reduces atherosclerosis in low density lipoprotein receptor-deficient mice. Mol Cell 2:275-281

16. Boisvert WA, Santiago R, Curtiss LK, Terkeltaub RA 1998 A leukocyte homologue of the IL-8 receptor CXCR-2 mediates the accumulation of macrophages in atherosclerotic lesions of LDL receptor-deficient mice. J Clin Invest 101:353-363

17. Qiao JH, Tripathi J, Mishra NK, Cai Y, Tripathi S, Wang XP, Imes S, Fishbein MC, Clinton SK, Libby P, Lusis AJ, Rajavashisth TB 1997 Role of macrophage colonystimulating factor in atherosclerosis: studies of osteopetrotic mice. Am J Pathol 150:1687-1699

18. Gupta S, Pablo AM, Jiang X, Wang N, Tall AR, Schindler C 1997 IFN-gamma potentiates atherosclerosis in ApoE knock-out mice. J Clin Invest 99:2752-2761

19. Lutgens E, Gorelik L, Daemen MJ, de Muinck ED, Grewal IS, Koteliansky VE, Flavell RA 1999 Requirement for CD154 in the progression of atherosclerosis. Nat Med 5:1313-1316

20. Mach F, Schonbeck U, Sukhova GK, Atkinson E, Libby P 1998 Reduction of atherosclerosis in mice by inhibition of CD40 signalling. Nature 394:200-203

21. Dong ZM, Chapman SM, Brown AA, Frenette PS, Hynes RO, Wagner DD 1998 The combined role of P- and E-selectins in atherosclerosis. J Clin Invest 102:145152

22. Collins RG, Velji R, Guevara NV, Hicks MJ, Chan L, Beaudet AL 2000 P-Selectin or intercellular adhesion molecule (ICAM)-1 deficiency substantially protects against atherosclerosis in apolipoprotein E-deficient mice. J Exp Med 191:189-194

23. Cybulsky MI, Iiyama K, Li H, Zhu S, Chen M, Iiyama M, Davis V, Gutierrez-Ramos JC, Connelly PW, Milstone DS 2001 A major role for VCAM-1, but not ICAM-1, in early atherosclerosis. J Clin Invest 107:1255-1262

24. Patel SS, Thiagarajan R, Willerson JT, Yeh ET 1998 Inhibition of alpha4 integrin and ICAM-1 markedly attenuate macrophage homing to atherosclerotic plaques in ApoEdeficient mice. Circulation 97:75-81

25. Bouayad A, Kajino H, Waleh N, Fouron JC, Andelfinger G, Varma DR, Skoll A, Vazquez A, Gobeil F Jr, Clyman RI, Chemtob S 2001 Characterization of PGE(2) receptors in fetal and newborn lamb ductus arteriosus. Am J Physiol Heart Circ Physiol 280:H2342-H2349

26. Clyman RI, Goetzman BW, Chen YQ, Mauray F, Kramer RH, Pytela R, Schnapp LM 1996 Changes in endothelial cell and smooth muscle cell integrin expression during closure of the ductus arteriosus: an immunohistochemical comparison of the fetal, preterm newborn, and full-term newborn rhesus monkey ductus. Pediatr Res 40:198 208

27. Springer TA 1990 Adhesion receptors of the immune system. Nature 346:425-434

28. Dansky HM, Charlton SA, Harper MM, Smith JD 1997 T and B lymphocytes play a minor role in atherosclerotic plaque formation in the apolipoprotein E-deficient mouse. Proc Natl Acad Sci U S A 94:4642-4646

29. Johnson-Tidey RR, McGregor JL, Taylor PR, Poston RN 1994 Increase in the adhesion molecule P-selectin in endothelium overlying atherosclerotic plaques. Coexpression with intercellular adhesion molecule-1. Am J Pathol 144:952-961

30. Davies MJ, Gordon JL, Gearing AJ, Pigott R, Woolf N, Katz D, Kyriakopoulos A 1993 The expression of the adhesion molecules ICAM-1, VCAM-1, PECAM, and E-selectin in human atherosclerosis. J Pathol 171:223-229

31. Kunkel EJ, Ley K 1996 Distinct phenotype of E-selectin-deficient mice. E-selectin is required for slow leukocyte rolling in vivo. Circ Res 79:1196-1204

32. Johnston B, Issekutz TB, Kubes P 1996 The alpha 4-integrin supports leukocyte rolling and adhesion in chronically inflamed postcapillary venules in vivo. J Exp Med 183:1995-2006

33. Gaboury JP, Kubes P 1994 Reductions in physiologic shear rates lead to CD11/CD18dependent, selectin-independent leukocyte rolling in vivo. Blood 83:345-350

34. Alon R, Kassner PD, Carr MW, Finger EB, Hemler ME, Springer TA 1995 The integrin VLA-4 supports tethering and rolling in flow on VCAM-1. J Cell Biol 128:1243-1253

35. Chen C, Mobley JL, Dwir O, Shimron F, Grabovsky V, Lobb RR, Shimizu Y, Alon R 1999 High affinity very late antigen-4 subsets expressed on T cells are mandatory for spontaneous adhesion strengthening but not for rolling on VCAM-1 in shear flow. J Immunol 162:1084-1095

36. Gerszten RE, Lim YC, Ding HT, Snapp K, Kansas G, Dichek DA, Cabanas C, Sanchez-Madrid F, Gimbrone MA Jr, Rosenzweig A, Luscinskas FW 1998 Adhesion of monocytes to vascular cell adhesion molecule-1-transduced human endothelial cells: implications for atherogenesis. Circ Res 82:871-878 
37. Walpola PL, Gotlieb AI, Cybulsky MI, Langille BL 1995 Expression of ICAM-1 and VCAM-1 and monocyte adherence in arteries exposed to altered shear stress. Arterioscler Thromb Vasc Biol 15:2-10

38. Gonzalez-Alvaro I, Munoz C, Garcia-Vicuna R, Sabando P, Cabanas C, SanchezMadrid F, Diaz-Gonzalez F 1998 Interference of nonsteroidal antiinflammatory drug with very late activation antigen 4/vascular cells adhesion molecule 1-mediated lymphocyte-endothelial cell adhesion. Arthritis Rheum 41:1677-1688

39. Knowles JW, Reddick RL, Jennette JC, Shesely EG, Smithies O, Maeda N 2000 Enhanced atherosclerosis and kidney dysfunction in eNOS(-/-)ApoE(-/-) mice are ameliorated by enalapril treatment. J Clin Invest 105:451-458

40. Clyman RI, Mauray F, Roman C, Heymann MA, Payne B 1983 Factors determining the loss of ductus arteriosus responsiveness to prostaglandin $\mathrm{E}_{2}$. Circulation 68:433-436

41. Clyman RI, Campbell D, Heymann MA, Mauray F 1985 Persistent responsiveness of the neonatal ductus arteriosus in immature lambs: a possible cause for reopening of patent ductus arteriosus after indomethacin induced closure. Circulation 71:141-145
42. Patel JN, Jager A, Schalkwijk C, Corder R, Douthwaite JA, Yudkin JS, Coppack SW, Stehouwer CD 2002 Effects of tumour necrosis factor-alpha in the human forearm: blood flow and endothelin-1 release. Clin Sci (Lond) 103:409-415

43. Johns DG, Webb RC 1998 TNF-alpha-induced endothelium-independent vasodilation: a role for phospholipase A2-dependent ceramide signaling. Am J Physio 275:H1592-H1598

44. Minghini A, Britt LD, Hill MA 1998 Interleukin-1 and interleukin-6 mediated skeletal muscle arteriolar vasodilation: in vitro versus in vivo studies. Shock 9:210-215

45. Hollenberg SM, Cunnion RE, Parrillo JE 1991 The effect of tumor necrosis factor on vascular smooth muscle. In vitro studies using rat aortic rings. Chest 100:1133-1137

46. Schmidt B, Davis P, Moddemann D, Ohlsson A, Roberts RS, Saigal S, Solimano A, Vincer M, Wright LL; Trial of Indomethacin Prophylaxis in Preterms Investigators 2001 Long-term effects of indomethacin prophylaxis in extremely-low-birth- weight infants. N Engl J Med 344:1966-1972 